INTERNATIONAL DESIGN CONFERENCE - DESIGN 2018

https://doi.org/10.21278/idc.2018.0377

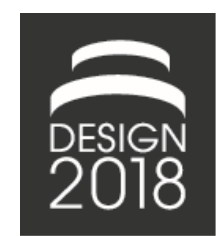

\title{
INTEGRATING SUSTAINABILITY IN PRODUCT REQUIREMENTS
}

\author{
M. Watz and S. I. Hallstedt
}

\begin{abstract}
Trade-offs between sustainability criteria and engineering design variables can lead to sub-optimisations and costly short-term priorities. This study explores how sustainability requirements can be identified and integrated in product requirements to guide strategic and tactical decisions in product development including sustainability perspectives. Literature review and action research resulted in a proposed systematic approach that: define sustainability criteria and indicators; use correlation analysis with QFD; and adds identified specific sustainability requirements to requirement list.
\end{abstract}

Keywords: sustainability, requirements management, early design phase, product development

\section{Introduction}

The sustainability performance of a product is highly dependent on decisions made early in the concept phase of product development (Hallstedt, 2017). In this phase, the basic components of a new design are conceptualised through identification of business opportunities, generation and selection of ideas, and, finally, product and technology development (Koen et al., 2001). Sustainability-related design variables are therefore important to identify and use in the early phases to guide a development towards more sustainable solutions (Byggeth et al., 2007). This research aims to explore and learn from previous research how sustainability requirements have been identified and integrated in the product requirements to guide product development.

Previous research has shown that there is a desire among product development practitioners to integrate sustainability criteria into decision support systems (Knight and Jenkins, 2009; Zetterlund et al., 2016). Sustainability aspects might otherwise be given less priority (Gaziulusoy et al., 2013). However, researchers have also concluded that decision support tools designed for sustainable product (and service) development lacks i) a strategic sustainability perspective (Zetterlund et al., 2016) and ii) support for tradeoffs between sustainability criteria and traditional design variables (Byggeth and Hochschorner, 2006). These deficiencies can result in sub-optimisations and short-term priorities in trade-off situations, which can be costly for the company in the long run. Furthermore, there is often a lack of a sustainability perspective that includes both an ecological and social sustainability perspective. These perspectives are sometimes separated, as social sustainability has been harder to define and quantify compared to ecological impacts. However, recent work with guidance on social responsibility by the International Standard Organization (SS-ISO, 2010) and UNEP's suggested guidelines for social life-cycle assessment of products (Benoît and Mazijn, 2009) as well as research, e.g., Missimer et al. (2017), have taken this a step further.

\section{Purpose and aim}

In the light of the perceived gap described above, and as sustainability criteria tend to be traded off in favor for traditional design variables (Bertoni, 2017), this study aims to explore i) how research up until 
now has approached integration of sustainability criteria in product requirements, and ii) how certain sustainability criteria were selected. The research questions are the following; What methods are being applied to facilitate integration of sustainability aspects into product requirements? How are sustainability criteria and indicators identified? In addition, a process that uses sustainability criteria to guide product requirements is suggested. The continuing of this paper is structured as follows; Section 2 outlines a background and description of strategic sustainable product development, Section 3 presents the methodological approach for this research study, Section 4 outlines the results of the literature review, and in Section 5 an introductory approach to strategically define sustainability aspects to consider in product development. Finally, a concluding discussion is held in Section 6, in which a novel process to guide integration of sustainability in requirements is presented.

\section{A strategic sustainability perspective in the product development process}

A strategic sustainability perspective means here that solutions are developed to fit into, or act as stepping stones to other solutions that will fit into, a future sustainable society defined from overarching sustainability principles (SPs) using a backcasting perspective (Dreborg, 1996). This means that in a sustainable society, nature is not subject to systematically increasing ... (SP1) ...concentrations of substances from the Earth's crust, (SP2) ...concentrations of substances produced by society, (SP3) ...degradations by physical means, and, in that society people are not subject to structural obstacles to ... (SP4) health, (SP5) influence, (SP6) competence, (SP7) impartiality, and, (SP8) meaning-making. (Broman and Robèrt, 2017; Missimer et al., 2017). This definition does not directly nor easily integrate into the product innovation process; i.e., the principles from a backcasting perspective do not constitute a tool that can simply be embedded into existing decision systems. In short, backcasting means imagining success in the future and then looking back to today to assess the present situation through the lens of this success definition, and to explore ways to reach that success (Dreborg, 1996; Vergragt and Quist, 2011). The challenge is to operationalize the sustainability principles and develop commercialized decision support tools. Therefore, previous research suggests informing other tools or integrate other tools that product developers use with SPs, e.g., Robèrt et al. (2002); Ny et al. (2006); Byggeth et al. (2007); Waage (2007); Thompson et al. (2012). More recent efforts involve both conceptual frameworks for strategic integration of sustainability into company decision making and the product development process, such as the Method for Integrated Product Development oriented to Sustainability (Fernandes et al., 2017). Examples of recent tactical support methods and tools, are Checklist for Sustainable Product Development (Schöggl et al., 2017) and the Sustainability Design Space (Hallstedt, 2017), aiming to provide designers and decision makers with strategic qualitatively obtained actions and indicators to be implemented in the early phases of product development. Although these approaches provide strategic guidance to select relevant sustainability criteria and indicators on strategic and tactical levels, they do not address how the criteria and indicators should be identified and integrated into product requirements on the operational level. In Bertoni (2017), operational decision level support is defined as tools to be used in the design environment for decision making, concept generation and down-selection between concepts, requirements and technologies. Tactical decision level support involves e.g. guidelines, indicators or support processes that are framed from the strategic decision level i.e. the top management business targets and strategies. Meta level refers to decision support that expands over more than one organisational decision level. These are the definitions that are applied in this study.

\section{The importance of product requirements for the product development process}

The design process is a process under which a product concept is being realised to a product description, a step prior to manufacturing in the product development process. This process is largely driven by product requirements which define the objectives that a design should fulfil, both in terms of structuraland performance aspects (Zeng and $\mathrm{Gu}, 1999)$. A requirement is a "statement that identifies a product or process operational, functional, or design characteristic or constraint, which is unambiguous, testable or measurable, and necessary for product or process acceptability (by consumers or internal quality assurance guidelines)" (IEEE, 2007). The requirement list is a key foundation for success in all projects, as it offers guidance and can be used for monitoring the decisions so that they lead towards the 
overall target, which is to satisfy stakeholder needs (Hull et al., 2005). Adequate requirements are necessary for guiding designers in developing solutions that perform well throughout the whole lifecycle, in regards to economic, ecological and social aspects (IEEE, 2007).

\section{Research approach}

The research approach of this paper consists of a combination of a systematic literature review and a prescriptive research study conducted at a case company.

\section{Systematic literature review}

A systematic review of previous publications, i.e., following a "transparent, rational and replicable" process (Tranfield et al., 2003), was applied to explore the state of the art of the research field, see Figure 1. The search architecture was obtained from two snowball sampling analyses (SBAs), i.e., a study of "references to references" (Wohlin, 2014), of previous academic publications discussing integration of sustainability into product development and requirements. The first SBA started in Jaghbeer et al. (2017), leading towards authors such as (Byggeth and Hochschorner, 2006; Bovea and Pérez-Belis, 2012; Inoue et al., 2012; Gaziulusoy et al., 2013; Hallstedt et al., 2013; Schöggl et al., 2016; Zetterlund et al., 2016; Hallstedt, 2017). A research map that visualised the referencing between these articles led towards (Hallstedt et al., 2013), which was chosen as a reference point for a second SBA. The second SBA led to authors such as (Kaebernick et al., 2003; Maxwell and Van der Vorst, 2003; Pujari et al., 2004; Lindahl, 2005; Byggeth and Hochschorner, 2006; Waage, 2007), and others.

From summarising and analysing frequency of keywords used in papers found in the SBAs, it was possible to build a concept map which was used as inspiration for the literature search. Frequently used key words, e.g., "sustainability", "criteria", "integration", "product requirement", etc., including similar words, terms or phrases, were used as operators in the search query. The same query was used to search in title, abstracts and key words in Scopus database and within 'topic' in the Web of Science (WoS) database. The searches were limited to journal papers, book chapters and conference proceedings written in English and published after 1999. A brief title and abstract screening was made for filtering the search results, using 'relevancy for integration of sustainability in product requirements' and 'relevancy for sustainability trade-offs' as criteria for inclusion (papers were considered 'relevant' even though only environmental aspects were considered). To complement the search results, a second, streamlined literature search was conducted in the same databases, although now only searching for titles in the Scopus database, but otherwise with the same limitations. The same filtering criteria were applied to the results in the second search. The first search queries combined keywords with relevant Boolean operators, for example, ("sustainab*" AND ("sustainab* product development" OR (similar term)) AND ("decision?making" OR "design requirement*" "product requirement ${ }^{* \prime}$ OR (similar term)), while the streamlined search combined words and terms such as ((product*development ${ }^{*}$ OR sustainable*product*development* OR (similar term)) AND (integrat* OR (similar term)). Remaining contributions were added through a third SBA. A first categorisation of papers was made based on the decision level architecture, namely meta, strategic, tactical and operational, as described above. The papers were thereafter sorted in regard to means to manage sustainability- and integration.

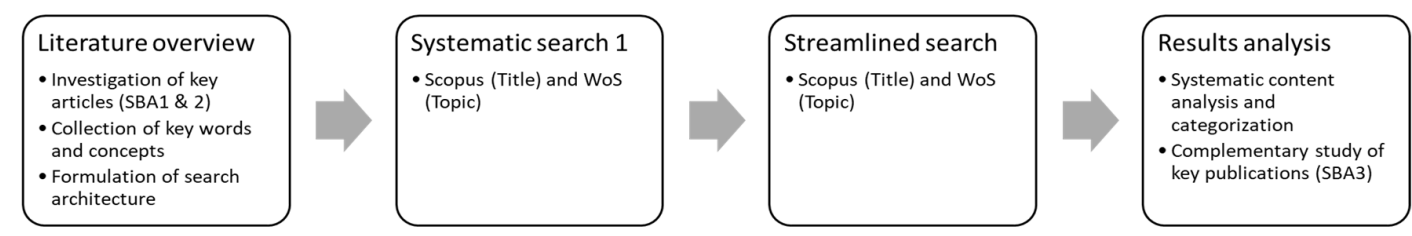

Figure 1. Schematic overview of the literature review process

\section{Action research}

A Sustainability Design Space, i.e. strategically tailored leading sustainability criteria, indicators for those, as well as the method itself together with a sustainability compliance index-scale, was developed for a case company in an action research-based study approach (Hallstedt, 2017). Action research 
(Avison et al., 1999) here meant an involvement of the researcher at the case company, working closelywith the design team during several years to understand and reflect on the challenges relevant for developing a Sustainability Design Space. This included several steps: i) gathering data and information about existing sustainability requirements and guidelines, which were crosschecked by using multiple sources to search for regularities and certainty in the data collection, ii) and iii) were descriptive studies in which key sustainability aspects were identified and a sustainability compliance index was formulated, as support for companies to estimate their sustainability maturity level (Hallstedt, 2017). Altogether about 20 company documents and reports, feedback from five workshops, assessment data and semi-structured interviews with product developers and engineers have been used to support the development of the prescriptive results. The findings were validated with pilot tests iv) and iteratively discussed with a design team, which consisted of an expert group of four engineers, active in the early phases of the technology- and product development process at the company. Leading sustainability criteria and indicators have been identified for the case company and are presented in the results.

The case company is an engine component manufacturer in the aerospace industry in which the research and development department were interested in increasing the capability to integrate a sustainability perspective in their decision-making system. Since an inability to clarify and understand the sustainability implications compared to performance features of concepts had been identified. Sustainability includes a rich set of features important for a successful introduction of new products and product-service solutions to the market. Therefore, a better understanding of relations between requirements and sustainability aspects and of how these can be included in the product requirement list was of interest to the case company.

\section{Literature review results}

This chapter will outline the results of the literature review in regards to: decision level in Section 4.1 and, integrated approaches with a sustainability perspective in Section 4.2.

\subsection{Sustainability integration efforts per decision level}

The literature review showed that efforts to integrate sustainability into product requirements can be found on all decision levels, with different sustainability perspectives and with support from different tools and methods. In total, 75 papers qualified in the initial filtering of the systematic search results. These papers were distributed into four categories; taxonomies and conceptual frameworks, strategic- and meta level efforts, tactical methods and tools and operational efforts, as have been described above. Sixteen of these papers were placed in the category of taxonomies and conceptual frameworks and were found useful for the interpretation of the other search results. They are however not described in more detail in this paper.

\section{Strategic decision level and meta-level}

Three of the papers described frameworks or methods for inclusion of sustainability in the product development process. Contributions taking place on this level included: the BECE framework (Mendoza et al., 2017) in which backcasting and eco-design are utilised to achieve alignment with circular economy principles; The Value Ideation process (Geissdoerfer et al., 2016) where design thinking is employed in the early innovation process to define alternative value drivers; and the Systemic double flow scenario method (Gaziulusoy et al., 2013) where product requirements are influenced from linking product development projects to societal structures. Four papers proposed meta-level perspectives, i.e., management of sustainability integration in the product development process (Brones and de Carvalho, 2015), including both concept generation (Maxwell and Van der Vorst, 2003; Waage et al., 2005; Waage, 2007) and redesign of a concept (Fargnoli et al., 2014).

\section{Tactical decision level}

Sixteen papers presented methods to obtain sustainability indicators, or to select design strategies to be used for decision making. Contributions that suggest approaches to defining sustainability-oriented key performance indicators (KPI) and that suggest when in the product development process they should be applied, include Method for integrated product development oriented to sustainability (Fernandes et al., 
2017), Checklist for Sustainable Product Development (Schöggl et al., 2017), Strategic eco-design map of the complex products (Keivanpour and Ait Kadi, 2017) and several others, see Table 1. The characteristic property of these contributions is that they offer support for defining sustainability focus areas and indicators for these, but without articulating how these supportive indicators and focus areas should be integrated in the product development process.

Table 1. Overview of strategic-, meta- and tactical approaches

\begin{tabular}{|c|c|c|c|}
\hline Decision level & Results & Name of method/tool & Reference \\
\hline \multirow[t]{2}{*}{ Meta/Strategic } & $\begin{array}{l}\text { Frameworks for implementation or } \\
\text { promotion of sustainability into the } \\
\text { product development process }\end{array}$ & BECE framework; Value ideation process; Systemic double-flow scenario method & $\begin{array}{l}\text { Mendoza et al. (2017); Geissdoerfer, Bocken } \\
\text { and Hultink (2016); Gaziulusoy et al. (2013) }\end{array}$ \\
\hline & $\begin{array}{l}\text { Modifications/ organisation of } \\
\text { product development management }\end{array}$ & $\begin{array}{l}\text { Design Management for Sustainability; Sustainability-oriented adaptations on the } \\
\text { product development process; Model for integrating ecological, social, and } \\
\text { financial factors into business decision-making; Method for Sustainable Product } \\
\text { Service Development }\end{array}$ & $\begin{array}{l}\text { Fargnoli et al. (2014); Waage (2007); Waage et } \\
\text { al. (2005); Maxwell and van der Vorst (2003) }\end{array}$ \\
\hline \multirow[t]{2}{*}{ Tactical } & Select sustainability-oriented KPI & $\begin{array}{l}\text { Strategic eco-design map of the complex products; Method for integrated } \\
\text { product development oriented to sustainability; Sustainability Design Space; } \\
\text { Guideline for the deployment of Product Requirements from Product-Related } \\
\text { Environmental Legislation; Material Criticality Assessment; Life cycle IndeX (LInX) }\end{array}$ & $\begin{array}{l}\text { Keivanpour and Ait Kadi (2017), Fernandes et } \\
\text { al. (2017); Hallstedt (2017); Hallstedt and } \\
\text { Isaksson (2017); Pigosso et al., (2016); Byggeth } \\
\text { et al. (2007); Khan, Sadiq and Veitch (2004) }\end{array}$ \\
\hline & $\begin{array}{l}\text { Select sustainability-oriented } \\
\text { focus/strategy }\end{array}$ & $\begin{array}{l}\text { Checklist for Sustainable Product Development; Integration of environmental and } \\
\text { business aspects toward sustainable product development; Methodology of } \\
\text { ecodesign for the development of more sustainable electro-electronic equipment }\end{array}$ & Schöggl et al. (2017) \\
\hline
\end{tabular}

\section{Operational decision level}

The largest category consisted of 34 papers describing operational efforts which integrated, and translated, sustainability indicators into product requirements. In contrast to the tactical approaches, operational efforts propose operational support for sustainability integration. Although most contributions combine several methods to facilitate integration, transformation and prioritisation of sustainability oriented aspects, it was possible to distinguish a main focus, see Table 2. Matrix-based tools, e.g., Quality Function Deployment (QFD), Functional Analysis (FA), Modular Design and Axiomatic Design (AD) tools were proposed in 23 of the 34 papers in this category, and thereby constituted the most frequently used approach. Less frequent approaches involved Preference Set-Based Design and Case-based reasoning, e.g. in Inoue et al. (2012), (Life cycle-) costing (Grote et al., 2007; Lu et al., 2011; Chan et al., 2014), and separate sustainability compliance requirements (Peças et al., 2013; Heintz et al., 2014; Ma and Okudan Kremer, 2014; Broeren et al., 2016). These efforts will not be assessed in more detail due to their low representation within the search results.

Table 2. Overview of operational approaches

\begin{tabular}{|l|c|l|l|}
\hline Main integrative approach & Number & References \\
\hline $\begin{array}{l}\text { Matrix tools; Functional Analysis; } \\
\text { Modular Analysis }\end{array}$ & 3 & Lacasa, Santolaya and Biederma nn (2016); La casa et al. (2015); Chou (2014); \\
Quality Function Deployment; & 18 & $\begin{array}{l}\text { (2016); Romli et al. (2015); Vinodh, Kamala and Jayakrishna (2014); Russo, Rizzi and Montelascini } \\
\text { (2014); Bereketli and Genevois (2013); Buyukozkan and Cifci (2013); Vinodh and Rathod (2011); } \\
\text { Zhang et al. (2011); Rathod, Vinodhb and Madhyasta (2011); Deva nathan et al. (2010); Sa kao } \\
\text { (2007); Kobayashi (2006); Kobayas hi et al. (2005); Kaebernick, Ka ra and Sun (2003); Masui (2003) }\end{array}$ \\
$\begin{array}{l}\text { Axiomatic Design } \\
\text { “Sustainability-compliance" } \\
\text { requirement } \\
\text { Preference Set-based Design / Case- } \\
\text { based-reasoning } \\
\text { Lifecycle costing/ cost focus }\end{array}$ & 2 & $\begin{array}{l}\text { Beng and Omar (2014); Morrison et al. (2013); } \\
\text { Broeren et al. (2016); Ma and Kremer (2015); Heintz, Belaud and Gerbaud (2014); Poudelet et al.. } \\
\text { (2013); Ng and Chuah (2012); Pecas et al. (2013) }\end{array}$ \\
\hline
\end{tabular}

Matrix tools are commonly used tools for translating different stakeholder requirements into product requirements to be targeted by designers. They use expertise to correlate the stakeholder requirements with traditional design parameters such as cost, weight, manufacturability and so forth. Modular Design and FA can also be combined with QFD, as found among the 15 QFD-focused papers, e.g., in Alemam and $\mathrm{Li}$ (2016) and Devanathan et al. (2010). The common characteristic for these approaches is that they 
semantically correlate sustainability (or rather environmental) aspects into functional requirements. In QFD, for instance, an eco-design strategy such as 'reduce material use' can be translated into the functional requirement of 'low product weight' (Romli et al., 2015; Alemam and Li, 2016; Salari and Bhuiyan, 2016). Similarly, AD and FA allow designers to construct design parameters from functional requirements, which can be oriented towards sustainability and evaluated in matrices (Morrison et al., 2013; Beng and Omar, 2014; Lacasa et al., 2015; Lacasa et al., 2016).

\subsection{Sustainability-oriented adaptions of the QFD process}

QFD came out as the most frequently used tool for integration of sustainability aspects in the process of generating product requirements and therefore this section will explore the method and its sustainability adaptions in more detail. QFD is a matrix tool that transforms customer requirements into technical- or product- requirements to be fulfilled by all steps in the product development process (ranging from strategies and planning, to manufacturing and sales) (Sullivan, 1986). The House of Quality (HoQ) is an essential part of the QFD, where different customer requirements, 'Voices of the Customer' (VoC), are mapped, classified, weighted and related to relevant engineering metrics (Akao, 1990). QFD is an important design tool as it encourages thorough understanding of customer preferences and priorities and because it "provides a tangible method to manage new product development" (Akao and Mazur, 2003). Several efforts have been made to integrate sustainability-oriented aspects into QFD with the aim to support the development of more sustainable products (Popoff and Millet, 2017). Examples will be described in the section below.

\section{Sustainability perspective}

The efforts found in this literature review mainly focus on cost, quality and environmental performance, few include social aspects. As described in Hallstedt (2017), a criterion can be defined as a target of a prioritized aspect or the level of the aspect that we strive for, e.g., "no raw material used" and "no hazardous chemicals used". An indicator can be defined as a measurement or fact, qualitative or quantitative, that can indicate the state or level of the criterion e.g., "material used in total and per unit of product" and "kilograms of persistent bio-accumulative and toxic chemicals used". The selection of environmental criteria or sustainability indicators can be managed either with support from assessment tools e.g., LCA or eco-design principles, or through an "ad hoc" approach. Ad hoc here refers to how sustainability requirements and indicators are chosen without support from an assessment that defines sustainability criteria with high relevance for the actual product or solution (Mitchell, 1996). An ad hoc approach can thus involve designer preferences or apply the same criteria as in previous research, without a strategic perspective (Ny et al., 2006). Zhang et al. (1999) made improvements to the Green QFD (GFD) (Cristofari et al., 1996) by incorporating life-cycle costing in the GQFDII. Kaebernick et al. (2003) propose the ECQFD, in which environmental performance is introduced as a new VoC in the QFD, where the results are evaluated with a LCA. Kobayashi et al. (2005) proposes using a simplified LCA endpoint analysis combined with a "willingness to pay analysis", i.e., considering human health, public assets, biodiversity and primary production capacity, to obtain an environmental impact driver. Another way to include environmental aspects is to use environmental aspects as VoC's. For instance, Masui et al. (2003) utilise ad hoc eco-design principles concerning, e.g., material and energy consumption, lifetime, end of life, emissions, maintenance, etc., to comply with environmental requirements from governments, recyclers and traditional customers while noting that LCA can be used to define critical design objectives. A similar approach is used in Vinodh et al. (2014), and in Salari and Bhuiyan (2016) where the Life Cycle Design Strategies are used to formulate customer requirements in a Green QFD. Romli et al. (2015) and Alemam and Li (2016) use eco-design strategies to formulate environmental criteria, to which ad hoc social considerations, such as human health and working conditions, are added. Recently, Popoff and Millet (2017) proposed the EcoCSP-QFD in which environmental performance, i.e., climate change, human health, ecosystem quality and resources, and costs are used to conduct the QFD. In contrast to these ad hoc efforts, Sakao (2007) suggests using LCA to define environmental hotspots to be translated into requirements. Table 3 summarises the sustainability approaches used by several authors. 
Table 3. Approaches to obtain sustainability criteria and indicators

\begin{tabular}{|c|c|c|c|c|c|c|c|c|c|}
\hline \multicolumn{4}{|c|}{ LCA or Eco-design principles } & \multicolumn{6}{|c|}{ AD hoc (LCA) indicators } \\
\hline Env. LCA and eco-design & $\begin{array}{l}\text { Env. LCA } \\
\text { and } \\
\text { stakehol } \\
\text { der } \\
\text { analysis }\end{array}$ & $\begin{array}{l}\text { Env. } \\
\text { LCA, } \\
\text { WTP }\end{array}$ & $\begin{array}{l}\text { Streamlined } \\
\text { (env.) LCA }\end{array}$ & $\begin{array}{l}\text { Climate Change, } \\
\text { Ecosystem Quality, } \\
\text { Human Health and } \\
\text { Resources, costs }\end{array}$ & $\begin{array}{l}\text { "Env. } \\
\text { VOC" }\end{array}$ & $\begin{array}{l}\text { Quality, } \\
\text { costs and } \\
\text { env. } \\
\text { indicator }\end{array}$ & $\begin{array}{c}\text { Env, Social, } \\
\text { Economic } \\
\text { indicators }\end{array}$ & $\begin{array}{l}\text { GWP and } \\
\text { E199 (triple- } \\
\text { bottom line } \\
\text { indicator) }\end{array}$ & $\begin{array}{l}\text { Eco-design } \\
\text { principle - } \\
\text { indicators }\end{array}$ \\
\hline $\begin{array}{l}\text { Romli et al. (2015); } \\
\text { Bereketli and Genevois } \\
\text { (2013); Buyukozkan and } \\
\text { Cifci (2013); Rathod et al. } \\
\text { (2011); Devanathan et al. } \\
\text { (2010); Sakao (2007) }\end{array}$ & $\begin{array}{l}\text { Zhang } \\
\text { et al. } \\
\text { (2011) }\end{array}$ & $\begin{array}{l}\text { Kobayas } \\
\text { hi et al. } \\
\text { (2005) }\end{array}$ & $\begin{array}{c}\text { Kaebernick, } \\
\text { Kara and Sun } \\
\text { (2003) }\end{array}$ & $\begin{array}{l}\text { Popoff and Millet } \\
\text { (2017) }\end{array}$ & $\begin{array}{l}\text { Vinod } \\
\mathrm{h} \text { and } \\
\text { Ratho } \\
\mathrm{d} \\
(2011)\end{array}$ & $\begin{array}{l}\text { Kobayash } \\
\text { i (2006) }\end{array}$ & $\begin{array}{l}\text { Masui } \\
(2003)\end{array}$ & $\begin{array}{l}\text { Vinodh et al. } \\
\text { (2014) }\end{array}$ & $\begin{array}{l}\text { Alemam and } \\
\text { Li (2016); } \\
\text { Germani et al. } \\
\text { (2016); Salari } \\
\text { and Bhuiyan } \\
\text { (2016) }\end{array}$ \\
\hline
\end{tabular}

\section{An introductory approach to identify and select sustainability indicators to guide product requirements}

Based on results from the action research the needs of the case company were: i) to better understand which product requirements that relate to sustainability; ii) to know what additional sustainability-related requirements need to be included; and, iii) to understand how to include these to the product requirement list. An introductory approach to define and select sustainability indicators to guide product requirement is therefore suggested. From the development of the Design Space, leading sustainability criteria and indicators were identified for the case company. Leading sustainability criteria for each life-cycle phase from the Sustainability Design Space were developed and selected to represent the most important sustainability aspects that can be accomplished within the time-constrained early development situation (Hallstedt and Isaksson, 2017). Indicators to the leading criteria were thereafter identified (Jaghbeer et al., 2017). These steps resulted in 23 criteria, 7 leading criteria and 11 indicators, see Figure 2.

\begin{tabular}{|c|c|c|c|c|}
\hline $\begin{array}{c}\text { Dedision aspects } \\
\text { concerning product }\end{array}$ & \multicolumn{4}{|c|}{ Sustainability aspects guided by Sustainability Principles (Broman and Robèrt, 2017; Missimer, 2015) } \\
\hline \begin{tabular}{|c|}
$\begin{array}{c}\text { Row moterioks } \\
\text { materials and } \\
\text { chemicals that are } \\
\text { used for the } \\
\text { product }\end{array}$ \\
\end{tabular} & $\begin{array}{l}\text { No risk-materials used } \\
\text { according to material } \\
\text { criticality list. }\end{array}$ & $\begin{array}{l}\text { No materials for products } \\
\text { and/or production used that } \\
\text { contain or result in emissions } \\
\text { of substances included in the } \\
\text { siN-list." }\end{array}$ & $\begin{array}{l}\text { No use of raw materials/ } \\
\text { chemicals and its } \\
\text { production that cause } \\
\text { physical degradation. }\end{array}$ & $\begin{array}{l}\text { No organizational practices at the suppliers of } \\
\text { raw moterials that create structural obstacles } \\
\text { for people's health, influence, competence, } \\
\text { impartiality and meaning-making. }\end{array}$ \\
\hline \multirow{2}{*}{$\begin{array}{l}\text { Production: } \\
\text { production by } \\
\text { suppliers of sub- } \\
\text { components \& } \\
\text { materials, as well as } \\
\text { production of } \\
\text { products at the } \\
\text { own company. }\end{array}$} & $\begin{array}{l}\text { Only recycled materials are } \\
\text { used, with no metal emissions } \\
\text { and all scrap metals are } \\
\text { recycled into pure fractions. }\end{array}$ & $\begin{array}{l}\text { No emissions and waste } \\
\text { products from production sites } \\
\text { (even at the suppliers) contain } \\
\text { substances in the SIN-list. }\end{array}$ & $\begin{array}{l}\text { No production of product } \\
\text { or product components } \\
\text { used that cause degradation } \\
\text { of Nature by physical } \\
\text { means. }\end{array}$ & $\begin{array}{l}\text { No organizational practices during production } \\
\text { and post processes that create structural } \\
\text { obstacles for people's health, influence, } \\
\text { competence, impartiality and meaning-making }\end{array}$ \\
\hline & $\begin{array}{l}\text { Only renewable energy sources } \\
\text { are used in the production } \\
\text { processes to become a } \mathrm{CO}^{2} \text {. } \\
\text { neutral facility and the energy } \\
\text { usaze in the production } \\
\text { processes are efficiently used. }\end{array}$ & & & \\
\hline \begin{tabular}{|c|} 
Distribution: \\
transportation of \\
matterials, \\
substances and \\
products connected \\
to the company \\
products snd its \\
production. \\
\end{tabular} & $\begin{array}{l}\text { Only renewable fuels are used } \\
\text { for distribution of materials, } \\
\text { substances and products. }\end{array}$ & $\begin{array}{l}\text { No emissions of green house } \\
\text { gases due to transportation of } \\
\text { materials, substances and } \\
\text { products from the company. }\end{array}$ & $\begin{array}{l}\text { No new land areas, } \\
\text { otherwise used for } \\
\text { renewewable resources and } \\
\text { reccreation, are used for } \\
\text { transportation of materials, } \\
\text { substances and/or } \\
\text { products. }\end{array}$ & 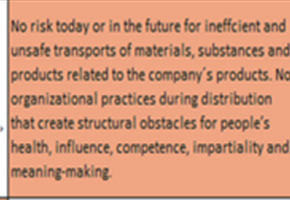 \\
\hline \multirow{2}{*}{$\begin{array}{l}\text { Uke and } \\
\text { Mointenonce: } \\
\text { activities and desien } \\
\text { that affect the } \\
\text { sustainability } \\
\text { impust during the } \\
\text { usage and } \\
\text { maintenance. }\end{array}$} & $\begin{array}{l}\text { Optimized desi in of the } \\
\text { product from a material and } \\
\text { energy perspective. }\end{array}$ & $\begin{array}{l}\text { The design of the product } \\
\text { contain no restricted } \\
\text { substances or moterials. }\end{array}$ & $\begin{array}{l}\text { The desizn of the product do } \\
\text { not contribute to } \\
\text { degradation of nature due } \\
\text { to nolse, odour or } \\
\text { emissions during use } \\
\text { ond/or maintenance of } \\
\text { ercoducts. }\end{array}$ & $\begin{array}{l}\text { Product use does not create structural } \\
\text { obstacles for people's health, influence, } \\
\text { competence, importiality and meoning-makine }\end{array}$ \\
\hline & & $\begin{array}{l}\text { No gretenhouse zas emissions } \\
\text { during the usage and } \\
\text { maintenance stage. }\end{array}$ & & $\begin{array}{l}\text { No organizational practices during } \\
\text { maintenance that creatt structural obstacles } \\
\text { for people's health, influence, competence, } \\
\text { imoartiglive and meaningemaking }\end{array}$ \\
\hline \begin{tabular}{|l|} 
End of lifece \\
activities and desien \\
that affect the \\
sustainability \\
import during the \\
end of life phose.
\end{tabular} & $\begin{array}{l}\text { All valuable } \\
\text { materials/component are } \\
\text { returned to the value chain for } \\
\text { remanufacturing and } \\
\text { rescycling. }\end{array}$ & $\begin{array}{l}\text { Emissions and waste from end } \\
\text { of life phase must not } \\
\text { contribute to an accumulation } \\
\text { in Nature. }\end{array}$ & $\begin{array}{l}\text { No physical degradation of } \\
\text { Nature caused by waste } \\
\text { from end of life phase. }\end{array}$ & $\begin{array}{l}\text { No organizational practices during end-of-life } \\
\text { activities that create structural obstacles for } \\
\text { people's health, influence, competence, } \\
\text { importisility and mesning-making }\end{array}$ \\
\hline
\end{tabular}
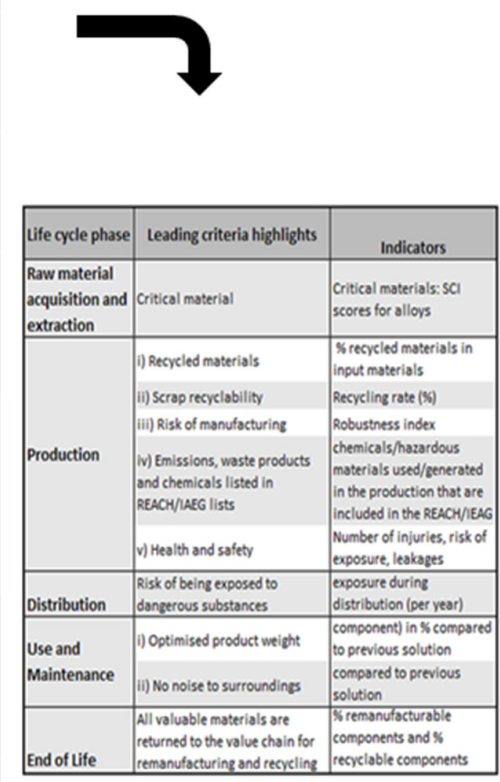

Figure 2. The case company sustainability criteria, the selected leading criteria (marked) and the sustainability indicators derived from the leading sustainability criteria 
This suggested approach does not give answers to how qualitative, and on which level of accuracy, sustainability data can be transferred into quantitative sustainability data in early design stages. For this, further studies are needed. In addition, a better understanding of the relationship and the influence between sustainability indicators and design requirements is needed to support the identifying of which sustainability requirements to add to the product requirement list in the early design phase. The main contribution of this work is to offer clear reasoning and a systematic support for how to select sustainability indicators to guide product requirements.

\section{Concluding discussion}

The aim and purpose of this paper was to present the current state of research regarding how to perform integration of sustainability criteria into product requirements. An explorative systematic literature review and a prescriptive research case study were conducted to answer the research questions.

How can sustainability criteria be integrated into product requirements, and what methods can be used?

In line with previous research, the importance of sustainability and how it should be integrated in the organisation is decided at a strategic decision level. Practical guidelines and systems to link the strategic objectives are formalised on a tactical decision level, as a means for communication. Product requirements can be interpreted as the operational means for guidance towards the business objectives (Hull et al., 2005). Whether sustainability is included in the product requirements can however be linked to the sustainability commitment on strategic and tactical levels (Schulte and Hallstedt, 2017). There are furthermore two main approaches to manage integration of sustainability criteria into the product requirements; i) as separate requirements such as complying with certain legislations and regulations, or ii) by relating sustainability criteria to traditional design requirements, e.g., relating "reduce material usage" to "low product weight" in a QFD (Masui et al., 2003; Romli et al., 2015; Popoff and Millet, 2017). The latter was most common within the literature review results, and QFD came out as the most frequently used tool. The sustainability perspective analysis was therefore limited to these results.

\section{How are sustainability criteria and indicators identified?}

In general, most of the articles focused on the environmental aspects of sustainability and the process for identifying sustainability criteria can be divided into two main perspectives: i) an environmental lifecycle assessment focus from which important sustainability aspects or eco-design strategies could be derived and integrated, or used to formulate separate sustainability requirements; and ii) an ad-hoc approach where no systematic strategy supported the selection of sustainability criteria. Both perspectives lack a full, strategic sustainability perspective, which indicates a gap between tactical efforts to sustainable product development and a gap of operational tools that support translation of sustainability criteria to product requirements.

\section{Proposed process to strategically integrate sustainability in product requirements}

In line with previous research, e.g., Bertoni (2017), the literature review concludes that tools on the operational level have most room for improvements. For example, tools for requirements generation lack a full sustainability perspective and have a tendency to lack a strategic process for defining suitable sustainability criteria and indicators to be integrated in the requirement list. The results from the prescriptive research case study showed that it is possible to obtain strategic sustainability criteria and indicators based on a full sustainability perspective. Since it is impossible to predict all future effects of unsustainable development, further research will focus on identifying and verifying sustainability indicators that can help companies to contribute to a sustainable development, and how these indicators can be implemented in the organisational environment.

Several operational matrix approaches, of which QFD was the most frequent tool, show that it can be possible to integrate sustainability criteria through correlation with traditional design requirements. From the results obtained in this study it is therefore proposed that sustainability is integrated in product requirements through a strategic approach that: i) defines sustainability criteria and indicators for those 
criteria; ii) correlates the sustainability criteria with design variables in a QFD; and, iii) adds to the requirement list the sustainability requirements that cannot be related to traditional design requirements.

\section{Next steps}

To improve and increase the use of this approach, future research will further investigate how sustainability criteria influence traditional design requirements and what the impact is from a selected design solution and from a sustainability perspective, e.g., via system dynamics modelling (Jaghbeer et al., 2017), or other techniques. A deeper understanding of these relations, and of the possibility to visualise and communicate these, could further be assessed considering their influence on the sustainability awareness and commitment throughout an organisation. This awareness could have an impact on, e.g., the weighting of requirements and or criteria in decision making tools. This is an element that was delimited from this study, and that could add to previous research on how sustainability aspects can be quantified, modelled and integrated into traditional value models for decision making, e.g., Hallstedt et al. (2015), Bertoni (2017) and Jaghbeer et al. (2017). The literature review results also contained a range of different efforts that apply Theory of Inventive Solving (TRIZ) or Algorithm of Inventive Solving (ARIZ) to support concept generation in the complex decision situation (Kobayashi, 2006; Rathod et al., 2011), Fuzzy logic to handle the uncertainty of variables (Bereketli and Erol Genevois, 2013) and Multicriteria Decision Making to support ranking between design concepts or requirements (Vinodh et al., 2014; Romli et al., 2016; Salari et al., 2016). Future research should also investigate further how these tools can support integration of a full sustainability perspective into the product development process.

\section{Acknowledgments}

The research leading to these results has received financial support from projects funded by the Knowledge Foundation at Blekinge Institute of Technology. Sincere thanks to the industrial research partner.

\section{References}

Akao, Y. (1990), Quality Function Deployment - Integrating Customer Requirements into Product Design, Productivity Press, Cambridge, MA.

Akao, Y. and Mazur, G.H. (2003), "The leading edge in QFD: past, present and future”, International Journal of Quality \& Reliability Management, Vol. 20 No. 1, pp. 20-35. https://doi.org/10.1108/02656710310453791

Alemam, A. and Li, S. (2016), "Matrix-based quality tools for concept generation in eco-design", Concurrent Engineering, Vol. 24 No. 2, pp. 113-128. https://doi.org/10.1177/1063293X15625097

Avison, D., Lau, F., Myers, M. and Nielsen, P.A. (1999), “Action Research”, Communications of the ACM, Vol. 42 No. 1, pp. 94-97. https://doi.org/10.1145/291469.291479

Beng, L.G. and Omar, B. (2014), "Integrating axiomatic design principles into sustainable product development", International Journal of Precision Engineering and Manufacturing-Green Technology, Vol. 1 No. 2, pp. 107117. https://doi.org/10.1007/s40684-014-0015-2

Benoît, C. and Mazijn, B. (2009), Guidelines for Social Life Cycle Assessment of Products, United Nations Environment Programme.

Bereketli, I. and Erol Genevois, M. (2013), “An integrated QFDE approach for identifying improvement strategies in sustainable product development”, Journal of Cleaner Production, Vol. 54, pp. 188-198. https://doi.org/10.1016/j.jclepro.2013.03.053

Bertoni, M. (2017), "Introducing Sustainability in Value Models to Support Design Decision Making: A Systematic Review", Sustainability, Vol. 9 No. 6. https://doi.org/10.3390/su9060994

Bovea, M.D. and Pérez-Belis, V. (2012), "A taxonomy of ecodesign tools for integrating environmental requirements into the product design process", Journal of Cleaner Production, Vol. 20 No. 1, pp. 61-71. https://doi.org/10.1016/j.jclepro.2011.07.012

Broeren, M.L.M., Molenveld, K., van den Oever, M.J.A., Patel, M.K., Worrell, E. and Shen, L. (2016), "Earlystage sustainability assessment to assist with material selection: a case study for biobased printer panels", Journal of Cleaner Production, Vol. 135, pp. 30-41. https://doi.org/10.1016/j.jclepro.2016.05.159

Broman, G.I. and Robèrt, K.-H. (2017), “A framework for strategic sustainable development”, Journal of Cleaner Production, Vol. 140, pp. 17-31. https://doi.org/10.1016/j.jclepro.2015.10.121

Brones, F. and de Carvalho, M.M. (2015), "From 50 to 1: Integrating literature toward a systemic ecodesign model", Journal of Cleaner Production, Vol. 96, pp. 44-47. https://doi.org/10.1016/j.jclepro.2014.07.036 
Byggeth, S. and Hochschorner, E. (2006), "Handling trade-offs in Ecodesign tools for sustainable product development and procurement", Journal of Cleaner Production, Vol. 14 No. 15-16, pp. 1420-1430. https://doi.org/10.1016/j.jclepro.2005.03.024

Byggeth, S., Broman, G. and Robèrt, K.-H. (2007), "A method for sustainable product development based on a modular system of guiding questions", Journal of Cleaner Production, Vol. 15 No. 1, pp. 1-11. https://doi.org/10.1016/j.jclepro.2006.02.007

Chan, H.K., Wang, X. and Raffoni, A. (2014), "An integrated approach for green design: Life-cycle, fuzzy AHP and environmental management accounting”, British Accounting Review, Vol. 46 No. 4, pp. 344-360. https://doi.org/10.1016/j.bar.2014.10.004

Cristofari, M., Deshmukh, A. and Wang, B. (1996), "Green quality function deployment", Proceedings of the 4th International Conference on Environmentally Conscious Design and Manufacturing, July 23 - 25, 1996, Cleveland, Ohio, pp. 297-304.

Devanathan, S., Ramanujan, D., Bernstein, W.Z., Zhao, F. and Ramani, K. (2010), "Integration of sustainability into early design through the function impact matrix", Journal of Mechanical Design, Vol. 132 No. 8, pp. 081004. https://doi.org/10.1115/1.4001890

Dreborg, K.H. (1996), "Essence of backcasting”, Futures, Vol. 28 No. 9, pp. 813-828. https://doi.org/10.1016/S0016-3287(96)00044-4

Fargnoli, M., De Minicis, M. and Tronci, M. (2014), "Design Management for Sustainability: An integrated approach for the development of sustainable products", Journal of Engineering and Technology Management, Vol. 34, pp. 29-45. https://doi.org/10.1016/j.jengtecman.2013.09.005

Fernandes, P.T., Canciglieri Júnior, O. and Sant'Anna, Â.M.O. (2017), "Method for integrated product development oriented to sustainability", Clean Technologies and Environmental Policy, Vol. 19 No. 3, pp. 775-793. https://doi.org/10.1007/s10098-016-1265-1

Gaziulusoy, A.I., Boyle, C. and McDowall, R. (2013), "System innovation for sustainability: A systemic doubleflow scenario method for companies", Journal of Cleaner Production, Vol. 45, pp. 104-116. https://doi.org/10.1016/j.jclepro.2012.05.013

Geissdoerfer, M., Bocken, N.M.P.P. and Hultink, E.J. (2016), "Design thinking to enhance the sustainable business modelling process - A workshop based on a value mapping process", Journal of Cleaner Production, Vol. 135, pp. 1218-1232. https://doi.org/10.1016/j.jclepro.2016.07.020

Grote, C.A., Jones, R.M., Blount, G.N., Goodyer, J. and Shayler, M. (2007), “An approach to the EuP Directive and the application of the economic eco-design for complex products", International Journal of Production Research, Vol. 45 No. 18-19, pp. 4099-4117. https://doi.org/10.1080/00207540701450088

Hallstedt, S.I. (2017), "Sustainability criteria and sustainability compliance index for decision support in product development", Journal of Cleaner Production, Vol. 140, pp. 251-266. https://doi.org/10.1016/j.jclepro.2015.06.068

Hallstedt, S.I. and Isaksson, O. (2017), "Material criticality assessment in early phases of sustainable product development", Journal of Cleaner Production, Vol. 161, pp. 40-52. https://doi.org/10.1016/j.jclepro.2017.05.085

Hallstedt, S.I., Bertoni, M. and Isaksson, O. (2015), "Assessing sustainability and value of manufacturing processes: A case in the aerospace industry", Journal of Cleaner Production, Vol. 108, pp. 169-182. https://doi.org/10.1016/j.jclepro.2015.06.017

Hallstedt, S.I., Thompson, A.W. and Lindahl, P. (2013), "Key elements for implementing a strategic sustainability perspective in the product innovation process", Journal of Cleaner Production, Vol. 51, pp. 277-288. https://doi.org/10.1016/j.jclepro.2013.01.043

Heintz, J., Belaud, J.P. and Gerbaud, V. (2014), "Chemical enterprise model and decision-making framework for sustainable chemical product design", Computers in Industry, Vol. 65 No. 3, pp. 505-520. https://doi.org/10.1016/j.compind.2014.01.010

Hull, E., Jackson, K. and Dick, J. (2005), Requirements Engineering, 2nd ed., SpringerLink, London. https://doi.org/10.1007/b138335

IEEE (2007), "IEEE Std 1220 TM -2005 Standard for Application and management of the systems engineering process", ISO/IEC 26702 IEEE Std 1220-2005 1st ed. 2007-07-15, Institute of Electrical and Electronics Engineers.

Inoue, M., Lindow, K., Stark, R., Tanaka, K., Nahm, Y.E. and Ishikawa, H. (2012), "Decision-making support for sustainable product creation", Advanced Engineering Informatics, Vol. 26 No. 4, pp. 782-792. https://doi.org/10.1016/j.aei.2012.07.002

Jaghbeer, Y., Hallstedt, S.I., Larsson, T. and Wall, J. (2017), "Exploration of simulation-driven support tools for sustainable product development", Proceedia CIRP, Vol. 64, pp. 271-276. https://doi.org/10.1016/j.procir.2017.03.069 
Kaebernick, H., Kara, S. and Sun, M. (2003), "Sustainable product development and manufacturing by considering environmental requirements", Robotics and Computer-Integrated Manufacturing, Vol. 19 No. 6, pp. 461-468. https://doi.org/10.1016/S0736-5845(03)00056-5

Keivanpour, S. and Ait Kadi, D. (2017), "Strategic eco-design map of the complex products: toward visualisation of the design for environment", International Journal of Production Research, pp. 1-17. https://doi.org/10.1080/00207543.2017.1388931

Knight, P. and Jenkins, J.O. (2009), "Adopting and applying eco-design techniques: a practitioners perspective", Journal of Cleaner Production, Vol. 17 No. 5, pp. 549-558. https://doi.org/10.1016/j.jclepro.2008.10.002

Kobayashi, H. (2006), "A systematic approach to eco-innovative product design based on life cycle planning", Advanced Engineering Informatics, Vol. 20 No. 2, pp. 113-125. https://doi.org/10.1016/j.aei.2005.11.002

Kobayashi, Y., Kobayashi, H., Hongu, A. and Sanehira, K. (2005), “A Practical Method for Quantifying Ecoefficiency Using Eco-design Support Tools”, Journal of Industrial Ecology, Vol. 9 No. 4, pp. 131-144. https://doi.org/10.1162/108819805775247990

Koen, P., Ajamian, G., Burkart, R., Clamen, A., Davidson, J. et al. (2001), "Providing clarity and a common language to the fuzzy front end", Research-Technology Management, Vol. 44 No. 2, pp. 46-55. https://doi.org/10.1080/08956308.2001.11671418

Lacasa, E., Santolaya, J.L. and Biedermann, A. (2016), “Obtaining sustainable production from the product design analysis", Journal of Cleaner Production, Vol. 139, pp. 706-716. https://doi.org/10.1016/j.jclepro.2016.08.078

Lacasa, E., Santolaya, J.L., Fuentes, L. and Majarena, A.C. (2015), "Implementing Sustainability Criteria in Product Development", Procedia Engineering, Vol. 132, pp. 1029-1036. https://doi.org/10.1016/j.proeng.2015.12.592

Lindahl, M. (2005), Engineering Designers' Requirements on Design for Environment Methods and Tools, PhD thesis, The Royal Institute of Technology.

Lu, B., Zhang, J., Xue, D. and Gu, P. (2011), "Systematic Lifecycle Design for Sustainable Product Development", Concurrent Engineering, Vol. 19 No. 4, pp. 307-324. https://doi.org/10.1177/1063293X11424513

Ma, J. and Okudan Kremer, G.E. (2014), "A fuzzy logic-based approach to determine product component end-oflife option from the views of sustainability and designer's perception", Journal of Cleaner Production, Vol. 108, pp. 289-300. https://doi.org/10.1016/j.jclepro.2015.08.029

Masui, K., Sakao, T., Kobayashi, M. and Inaba, A. (2003), "Applying Quality Function Deployment to environmentally conscious design”, International Journal of Quality \& Reliability Management, Vol. 20 No. 1, pp. 90-106. https://doi.org/10.1108/02656710310453836

Maxwell, D. and Van der Vorst, R. (2003), "Developing sustainable products and services", Journal of Cleaner Production, Vol. 11 No. 8, pp. 883-895. https://doi.org/10.1016/S0959-6526(02)00164-6

Mendoza, J.M.F., Sharmina, M., Gallego-Schmid, A., Heyes, G. and Azapagic, A. (2017), "Integrating Backcasting and Eco-Design for the Circular Economy: The BECE Framework", Journal of Industrial Ecology, Vol. 21 No. 3, pp. 526-544. https://doi.org/10.1111/jiec.12590

Missimer, M., Robèrt, K.-H. and Broman, G. (2017), "A strategic approach to social sustainability - Part 2: a principle-based definition", Journal of Cleaner Production, Vol. 140 No. 1, pp. 42-52. https://doi.org/10.1016/j.jclepro.2016.04.059

Mitchell, G. (1996), "Problems and fundamentals of sustainable development indicators", Sustainable Development, Vol. 4 No. 1, pp. 1-11. https://doi.org/10.1002/(SICI)1099-1719(199603)4:1<1::AID$\mathrm{SD} 24>3.0 . \mathrm{CO} ; 2-\mathrm{N}$

Morrison, J.R., Azhar, M., Lee, T. and Suh, H. (2013), “Axiomatic Design for eco-design: eAD+”, Journal of Engineering Design, Vol. 24 No. 10, pp. 711-737. https://doi.org/10.1080/09544828.2013.822150

Ny, H., MacDonald, J.P., Broman, G., Yamamoto, R. and Robèrt, K.-H. (2006), "Sustainability Constraints as System Boundaries: An Approach to Making Life-Cycle Management Strategic", Journal of Industrial Ecology, Vol. 10 No. 1-2, pp. 61-77. https://doi.org/10.1162/108819806775545349

Peças, P., Ribeiro, I., Silva, A. and Henriques, E. (2013), "Comprehensive approach for informed life cycle-based materials selection”, Materials and Design, Vol. 43, pp. 220-232. https://doi.org/10.1016/j.matdes.2012.06.064

Popoff, A. and Millet, D. (2017), "Sustainable life cycle design using Constraint Satisfaction Problems and Quality Function Deployment”, Procedia CIRP, Vol. 61, pp. 75-80. https://doi.org/10.1016/j.procir.2016.11.147

Pujari, D., Peattie, K. and Wright, G. (2004), "Organizational antecedents of environmental responsiveness in industrial new product development”, Industrial Marketing Management, Vol. 33 No. 5, pp. 381-391. https://doi.org/10.1016/j.indmarman.2003.09.001

Rathod, G., Vinodhb, S. and Madhyasta, U.R. (2011), "Integration of ECQFD and LCA for enabling sustainable product design in an electric vehicle manufacturing organisation", International Journal of Sustainable Engineering, Vol. 4 No. 3, pp. 202-214. https://doi.org/10.1080/19397038.2010.547624 
Robèrt, K.H., Schmidt-Bleek, B., Aloisi De Larderel, J., Basile, G., Jansen, J.L. et al. (2002), "Strategic sustainable development - Selection, design and synergies of applied tools", Journal of Cleaner Production, Vol. 10 No. 3, pp. 197-214. https://doi.org/10.1016/S0959-6526(01)00061-0

Romli, A., Prickett, P., Setchi, R. and Soe, S. (2015), "Integrated eco-design decision-making for sustainable product development”, International Journal of Production Research, Vol. 53 No. 2, pp. 549-571. https://doi.org/10.1080/00207543.2014.958593

Sakao, T. (2007), "A QFD-centred design methodology for environmentally conscious product design", International Journal of Production Research, Vol. 45, pp. 4143-4162. https://doi.org/10.1080/00207540701450179

Salari, M. and Bhuiyan, N. (2016), "A new model of sustainable product development process for making tradeoffs", The International Journal of Advanced Manufacturing Technology, Vol. 94 No. 1-4, pp. 1-11. https://doi.org/10.1007/s00170-016-9349-y

Schöggl, J.P., Baumgartner, R.J. and Hofer, D. (2017), "Improving sustainability performance in early phases of product design: A checklist for sustainable product development tested in the automotive industry", Journal of Cleaner Production, Vol. 140, pp. 1602-1617. https://doi.org/10.1016/j.jclepro.2016.09.195

Schulte, J. and Hallstedt, S.I. (2017), "Challenges for integrating sustainability in risk management - Current state of research", Proceedings of ICED ' $17 /$ the $21^{\text {st }}$ International Conference on Engineering Design, Vol. 2, August 21 - 25, 2017, Vancouver, Canada, The Design Society, Glasgow, pp. 327-336.

SS-ISO (2010), Guidance on social responsibility (ISO 26000:2010, IDT), Swedish Standards Institute, Stockholm, Sweden.

Sullivan, L.P. (1986), “Quality function deployment”, Quality Progress, Vol. 19 No. 16, pp. 39-50.

Thompson, A., Hallstedt, S. and Isaksson, O. (2012), "Introductory approach for sustain- ability integration in conceptual design", Proceedings of the DESIGN 2012 / 12th International Design Conference, Dubrovnik, Croatia, May 21 - 24, 2012, pp. 1151-1160.

Tranfield, D., Denyer, D. and Smart, P. (2003), “Towards a Methodology for Developing Evidence-Informed Management Knowledge by Means of Systematic Review”, British Journal of Management, Vol. 14 No. 3 , pp. 207-222. https://doi.org/10.1111/1467-8551.00375

Vergragt, P.J. and Quist, J. (2011), "Backcasting for sustainability: Introduction to the special issue", Technological Forecasting and Social Change, Vol. 78 No. 5, pp. 747-755. https://doi.org/10.1016/j.techfore.2011.03.010

Vinodh, S., Kamala, V. and Jayakrishna, K. (2014), "Integration of ECQFD, TRIZ, and AHP for innovative and sustainable product development", Applied Mathematical Modelling, Vol. 38 No. 11-12, pp. 2758-2770. https://doi.org/10.1016/j.apm.2013.10.057

Waage, S.A. (2007), "Re-considering product design: a practical 'road-map' for integration of sustainability issues", Journal of Cleaner Production, Vol. 15 No. 7, pp. 638-649. https://doi.org/10.1016/j.jclepro.2005.11.026

Waage, S.A., Geiser, K., Irwin, F., Weissman, A.B., Bertolucci, M.D. et al. (2005), "Fitting together the building blocks for sustainability: A revised model for integrating ecological, social, and financial factors into business decision-making", Journal of Cleaner Production, Vol. 13 No. 12, pp. 1145-1163. https://doi.org/10.1016/j.jclepro.2004.06.003

Wohlin, C. (2014), "Guidelines for snowballing in systematic literature studies and a replication in software engineering", Proceedings of the 18th International Conference on Evaluation and Assessment in Software Engineering (EASE '14), London, UK, May 13-14, 2014, ACM, New York. https://doi.org/10.1145/2601248.2601268

Zeng, Y. and Gu, P. (1999), “A science-based approach to product design theory Part II: formulation of design requirements and products", Robotics and Computer-Integrated Manufacturing, Vol. 15 No. 4, pp. 341-352. https://doi.org/10.1016/S0736-5845(99)00029-0

Zetterlund, H., Hallstedt, S. and Broman, G. (2016), "Implementation Potential of Sustainability-oriented Decision Support in Product Development", Procedia CIRP, Vol. 50, pp. $287-292$. https://doi.org/10.1016/j.procir.2016.05.011

Matilda Maria Louise Watz, PhD Candidate

Blekinge Institute of Technology, Department of Strategic Sustainable Development

Ga Infartsvägen 3A, 37141 Karlskrona, Sweden

Email: matilda.watz@bth.se 